\title{
ANALISIS KEWAJIBAN ALIH TEKNOLOGI DALAM INVESTASI ASING DI INDONESIA ${ }^{*}$
}

\author{
Endah Sulastri ${ }^{1}$ \\ Permalink: https://www.academia.edu/9998032
}

\begin{abstract}
An Analysis on Technology Transfer in Foreign Investment in Indonesia. Investment in globalization era is actively done by developed countries. The considerations are related to the availability of resources, cheap labor and to get benefits from great expansion on the market. The availability of this investment gives benefit to the developing countries, because it helps the countries to improve their infrastructures, decrease jobless rate by providing job opportunities, and the main important is the technology transfer from experts working in Indonesia to national workers.
\end{abstract}

Keywords: globalization, investment, technology transfer

Abstrak: Analisis Kewajiban Alih Teknologi Dalam Investasi Asing di Indonesia. Investasi di era globalisasi ini semakin giat dilakukan oleh negara-negara maju. Pertimbangannya berkaitan dengan ketersediaan bahan baku, tenaga kerja yang murah serta dalam rangka ekspansi pasar. Keberadaan investasi ini memberikan manfaat bagi negara-negara berkembang, karena dengannya negara-negara tersebut dapat melakukan pembangunan infrastruktur, mengurangi angka pengangguran dengan menyerap tenaga kerja dalam jumlah besar, dan yang paling pokok di sini ialah adanya alih atau transfer teknologi dari tenaga expert yang bekerja di Indonesia kepada tenaga kerja nasional.

Kata Kunci: globalisasi, investasi, alih atau transfer teknologi

* Diterima tanggal naskah diterima: 11 September 2014, direvisi: 25 Oktober 2014, disetujui untuk terbit: 12 November 2014.

${ }^{1}$ Kantor Hukum Adisuryo \& Co. Jl. HR. Rasuna Said Gedung Setiabudi lt 6 Suite 605C Jakarta. E-mail: endah_sulastri@ymail.com 


\section{Pendahuluan}

Dunia saat ini tengah berada pada era global, yang menyebabkan semua kawasan di seluruh dunia saling terkait dan terintegrasi.Globalisasi tersebut terjadi di berbagai aspek salah satunya pada aspek ekonomi. Proses globalisasi ekonomi adalah perubahan perekonomian dunia yang bersifat mendasar, dan proses ini akan berlangsung terus dengan laju yang semakin cepat mengikuti perubahan teknologi yang juga semakin cepat. ${ }^{2}$

Sebagai negara dengan prinsip ekonomi terbuka, Indonesia tidak dapat menghindar dari era perdagangan bebas ${ }^{3}$ yang merupakan bagian dari penerapan globalisasi. Pada era global ini hampir tidak dapat dilihat adanya batas-batas negara dan besarnya bumi.Hal ini disebabkan lalu lintas modal, perdagangan, dan informasi teknologi berjalan dengan sangat cepat.Era globalisasi ini sangat erat kaitannya dengan era liberalisasi perdagangan.

Pada dasarnya negara maju adalah pihak yang paling diuntungkan dalam era liberalisasi perdagangan seperti saat ini, sebab negara maju memiliki keunggulan dalam berbagai hal yang tidak dimiliki oleh negara berkembang seperti kestabilan perekonomian, teknologi tinggi, industri yang produktif, dan lain sebagainya.

Investasi di era globalisasi ini semakin giat dilakukan oleh negaranegara maju. Beberapa pertimbangan adalah berkaitan dengan ketersediaan bahan baku, tenaga kerja yang murah serta dalam rangka ekspansi pasar. Keberadaan investasi asing bagi negara berkembang terbagi atas 2 teori yang memandangnya, yakni dari sudut pandang teori klasik (classic theory), keberadaan investasi ini memberikan manfaat bagi negara-negara berkembang karena melalui investasi ini negara-negara tersebut dapat melakukan pembangunan infrastruktur, mengurangi angka pengangguran dengan menyerap tenaga kerja dalam jumlah besar, dan yang paling pokok di sini ialah adanya alih atau transfer teknologi dari tenaga expert yang bekerja di Indonesia kepada tenaga kerja nasional.

Berbeda dengan pemikiran teori klasik (classic theory, teori ketergantungan (dependency theory) memandang bahwa keberadaan investasi hanya membawa sifat konsumtif dan ketergantungan saja bagi negara-negara berkembang. Hal ini tentunya sangat bertentangan dengan apa yang menjadi cita-cita luhur para founding fathers kita yang menginginkan adanya kedaulatan serta kemandirian di semua aspek kehidupan nasional termasuk di sini adalah dalam aspek perekonomian.

\footnotetext{
2 Tulus TH. Tambunan, Globalisasi dan Perdagangan Internasional, (Bogor; Ghalia Indonesia 2004), h. 1.

3"Dalam era perdagangan bebas, hakikat persaingan menjadi lebih luas sehingga meliputi persaingan di antara negara-negara industri maju, persaingan antara negara-negara industri maju dengan negara-negara berkembang dan persaingan di antara negara-negara berkembang" dikutip dari Ranti Fauza Mayana, Perlindungan Desain Industri Di Indonesia dalam Era Perdagangan Bebas, (Jakarta; Grasindo, 2004), h. 2.

${ }^{4}$ Rustanto, Hukum Nasionalisasi Modal Asing, (Jakarta; Kuwais, 2012), h. 65.
} 
Keberadaan investasi asing memiliki karakteristik dan kelebihan berupa: ${ }^{5}$ a). Sifatnya permanen atau jangka panjang; b). Memberi andil alih teknologi; c). Memberi andil dalam alih keterampilan; d). Membuka lapangaan kerja baru.

Kewajiban alih teknologi merupakan bagian dari asas dan tujuan dalam investasi yang tertuang dalam pasal 3 Undang-Undang No 25 Tahun 2007 tentang Penanaman Modal. Namun secara das sein tujuan investasi asing yang berkaitan dengan adanya alih teknologi belum nampak secara riil dalam perkembangan kemampuan sumber daya manusia nasional. Dalam aturan yang terpisah alih teknologi ini juga diatur dalam beberapa peraturan perundangundangan, seperti Undang-Undang Nomor 18 Tahun 2002 tentang Sistem Nasional Penelitian, Pengembangan, dan Penerapan Ilmu Pengetahuan dan Teknologi. ${ }^{6}$

\section{Investasi di Indonesia}

Tujuan dan arah pembangunan nasional sebagaimana ditetapkan dalam Program Pembangunan Nasional (Propenas) yakni, berusaha mewujudkan masyarakat adil dan makmur, di mana masyarakat yang adil dan makmur itu akan diwujudkan melalui pembangunan di berbagai bidang, salah satunya adalah bidang ekonomi.

Pelaksanaan pembangunan seperti diketahui membutuhkan modal dalam jumlah yang besar dan harus tersedia pada waktu yang tepat. Modal ini dapat disediakan oleh pemerintah, masyarakat, atau pihak swasta nasional. Dalam keadaan yang ideal modal tersebut dapat dipenuhi dengan kemampuan modal dalam negeri sendiri. Namun dalam kenyataannya tidaklah demikian, sebab pada umumnya negara-negara berkembang mengalami hambatan dalam hal ketersediaan modal dalam negeri. ${ }^{7}$

Demikian pula yang terjadi di Indonesia setelah mengalami masa-masa kolonialisasi yang cukup panjang, pada awal kemerdekaan negeri ini mencoba untuk memulai melaksanakan pembangunan di semua sektor. Namun kenyataan lain menunjukkan bahwa tingkat ketersediaan modal dalam negeri sangat tidak mencukupi untuk dapat melaksanakan pembangunan nasional.

Pasca proklamasi, kebijakan penanaman modal asing (PMA) di Indonesia mengalami pasang surut mengikuti perkembangan politik dan ekonomi. PMA pertama kali diatur dengan Undang-Undang Nomor 78 Tahun 1958 tentang Penanaman Modal yang kemudian diubah dengan UU Nomor 15 Tahun 1960 dan kemudian dicabut dengan UU Nomor 16 Tahun $1965 .{ }^{\circ}$

Pasang-surut iklim PMA di Indonesias tak lepas dari pengaruh perekonomian pada masa Orde Lama yang memburuk karena keadaan politik

\footnotetext{
5 Salim H.S. dan Budi Sutrisno, Hukum Investasi, (Jakarta; Rajagrafindo Persada, 2008), h. 38.

${ }^{6}$ Sabartua Tampubolon, Politik Hukum Iptek di Indonesia, Cetakan I, (Yogyakarta;
} Kepel Press, 2013), h. 258.

${ }^{7}$ Ibid, h. 2.

${ }^{8}$ Rustanto, Hukum Nasionalisasi Modal Asing. Cet-I, (Jakarta: Kuwais, 2012), h. 52. 
dalam negeri yang mengalami kekacauan, puncaknya dengan adanya Gerakan 30 S/PKI pada tahun 1965, yang menjadi momentum beralihnya pemerintahan rezim Orde Lama ke rezim Orde Baru. ${ }^{9}$ Berkat kemampuan rezim Orde Baru dalam meyakinkan negara-negara donor, Indonesia memperoleh pinjaman luar negeri serta berimbas pada meningkatnya kepercayaan negara-negara maju yang tergabung baik dalam IGGI maupun World Bank.

Persoalan baru mulai timbul manakala perekonomian dunia mengalami resesi ${ }^{10}$. Dalam proses tersebut kebanyakan negara-negara maju menjadi lebih tertutup, sehingga menimbulkan kesulitan bagi negara-negara berkembang yang mendapat bantuan aliran dana dari luar negeri. Keadaan tersebut memaksa negara-negara berkembang tak terkecuali Indonesia untuk mencari alternatif lain selain dalam bentuk pinjaman luar negeri yakni dengan menggalakkan penanaman modal khususnya penanaman modal asing (foreign direct investment).

Dalam investasi asing di Indonesia terdapat asas asas yang menjadi dasar penyelenggaraannya. Asas-asas hukum investasi ini yang menjadi acuan dalam melaksanakan hal-hal yang berkaitan dengan penyelenggaraan kebijakan investasi di Indonesia. Asas dalam hukum investasi meliputi; kepastian, keterbukaan, akuntabilitas, perlakuan yang sama dan tidak membedakan asal negara, kebersamaan, efisiensi berkeadilan, berkelanjutan, berwawasan lingkungan, kemandirian, keseimbangan kemajuan dan kesatuan ekonomi nasional. ${ }^{11}$

\section{Alih Teknologi}

Indonesia adalah negara ironi, kalimat tersebut memulai sebuah essai yang ditulis oleh Doty Damayanti dalam essainya yang berjudul "Negara Bersumber Daya yang Tidak Berdaya". Hal ini senada dengan pernyataan Jonathan Pincus, peneliti dari Harvard Kennedy School, menyebut Indonesia gagal memanfaatkan peluang yang terbuka dari era globalisasi. Hal ini ditandai dengan ekspor Indonesia yang masih didominasi sumber daya alam dalam bentuk mentah ${ }^{12}$, Indonesia tidak masuk dalam produksi global, dan investasi asing hanya berkonsentrasi pada sektor eksploitasi sumber daya alam. ${ }^{13}$

${ }^{9}$ Pada tahun 1965 berlaku Undang-Undang Nomor 16 Tahun 1965 tentang Pencabutan Undang-Undang No. 78 Tahun 1958 tentang Penanaman Modal Sebagaimana Telah Diubah Dan Ditambah Dengan Undang-Undang No. 15 Prp. Tahun 1960. Alasan pencabutan Undang-Undang ini adalah untuk melaksanakan prinsip berdiri di atas kaki sendiri di bidang ekonomi dan prinsip Dekon (Deklarasi Ekonomi). Lihat Rustanto, Hukum Nasionalisasi Modal Asing. Cet-I, (Jakarta: Kuwais, 2012), h. 56.

${ }^{10}$ Seperti krisis yang bersumber pada pasar surat utang subprime mortgage di AS pada 2007-2008 yang menghantui terjadinya resesi ekonomi global. Begitu pula yang terjadi di negaranegara Asia, termasuk Indonesia, yang memiliki relevansi dalam konteks krisis tahun 1997-1998 lalu. Krisis finansial yang terjadi bahkan merembet menjadi krisis ekonomi, krisis politik, bahkan krisis sosial budaya. Lihat Prasetyantoko, Bencana Finansial, (Jakarta:Kompas, 2008), h. 21.

${ }^{11}$ Asas dan tujuan investasi di Indonesia dapat dilihat dalam Pasal 3 Undang-Undang No.25 Tahun 2007 tentang Penanaman Modal.

${ }^{12}$ Mengenai ekspor larangan barang mentah Indonesia mengeluarkan Peraturan Pemerintah No. 1 Tahun 2014 Perubahan kedua atas PP No. 23 Tahun 2010 tentang Kegiatan 
Di satu sisi Indonesia merupakan negara yang beruntung dengan Sumber Daya Alam (SDA) yang lengkap, mulai dari minyak bumi, batu bara, gas, hingga mineral lainnya. Seluruh potensi energi itu tidak hanya bisa mengumpulkan devisa, melainkan juga menghasilkan efek bergulir yang menggerakkan ekonomi nasional.

Poin permasalahan di sini adalah semua SDA tersebut merupakan SDA yang tidak terbarukan, eksploitasi secara terus-menerus maka akan mengurangi ketersediaanya di alam bahkan menghabiskannya. Bertolak dari SDA yang tidak terbarukan tersebut seharusnya Indonesia tidak hanya mempertahankan orientasi pada sektor primer saja melainkan harus mulai merubah paradigma untuk juga berorientasi pada sektor sekunder dan tersier. ${ }^{14}$ Perubahan paradigma ini tentunya juga harus dibarengi dengan peningkatan standar mutu Sumber Daya Manusia (SDM) sendiri berkaitan dengan penguasaan teknologi yang berguna dalam mendukung pengolahan potensi dalam negeri. Dalam hal ini beberapa negara berkembang lainnya telah melakukan dalam tataran praktis apa yang dikenal dengan alih teknologi.

Dalam referensi mengenai alih teknologi, para peneliti biasanya selalu mengacu pada definisi alih teknologi yang terdapat dalam dokumen Transnatioal Coorporations and Technology Transfer: Effects and Policy Issues. Dalam dokumen tersebut definisi alih teknologi secara lengkap disebutkan sebagai berikut:

"The word "technology" itself used in at least two senses. In the first, it means technical knowledge related or know-how-that is, knowledge, the methods and techniques of production of goods and services. In the sense it may include the human skills required for the apllication of techniques, since it is difficult to separate such application from a knowledge of the techniques themselves. In the second, broader sense, "technology" also encompasses capital themselves the embodiment of technical knowledge. In some instance, the term "embodied technology" is used to distinguish capital goods from technical knowledge proper" ${ }^{\text {"s }}$ (kata teknologi sendiri setidaknya digunakan dalam dua sudut pandang, pertama, ini berarti berhubungan pengetahuan teknis atau tentang bagaimana, pengetahuan, metode dan teknik produksi barang-barang dan jasa. Pengertian lain juga termasuk persyaratan kemampuan manusia untuk menerapkan teknik, karena sulit dipisahkan penerapan pengetahuan dari teknik itu sendiri. Kedua, pemikiran secara luas teknologi juga meliputi modal sendiri perwujudan dari teknik pengetahuan. Dalam beberapa contoh, istilah

Usaha Pertambangan Mineral dan Batubara atau biasa yang dikenal dengan Larangan Ekspor Mineral Mentah.

${ }^{13}$ Doty Damayanti, Negara Bersumber Daya yang Tidak Berdaya. Dalam Mulyawan Karim, ed. Rindu Pancasila, (Jakarta: Kompas Media Nusantara, 2010), h. 189.

${ }^{14}$ Sektor industri terbagi atas 3 kategori, yakni industri primer (pertanian, pertambangan, dan ekstraksi minyak bumi), industri sekunder (manufaktur serta jenis-jenis produksi lain), dan industri tertier (jasa dan real estate). Lihat Rustanto, Hukum Nasionalisasi Modal Asing. Cet-I, (Jakarta: Kuwais, 2012), h. 62.

${ }^{15}$ UNCTC, Transnational Corporations and Technology Transfer: Effects and Policy Issues, United Nation, 1987, h. 1. 
perwujudan teknologi, digunakan membedakan modal berupa barang dengan teknologi tepat guna)

Dalam Pasal 1 angka 11 disebutkan bahwa "Alih teknologi adalah pengalihan kemampuan memanfaatkan dan menguasai ilmu pengetahuan dan teknologi antar lembaga, badan, atau orang, baik yang berada di lingkungan dalam negeri maupun yang berasal dari luar negeri ke dalam negeri dan sebaliknya".

Selanjutnya, cara atau sarana melakukan alih teknologi diuraikan sebagai berikut:

Pertama; Foreign direct investment. Foreign direct investment adalah bentuk mekanisme alih teknologi seperti yang telah dijabarkan sebelumnya bahwa dengan adanya foreign direct investment maka akan terjadi ekspansi pasar. Ekspansi pasar ini melalui pembentukan perusahaan-perusahaan PT PMA di Indonesia telah membawa masuk teknologi asing.PT PMA membuat kontrak dan melalui kontrak inilah teknologi masuk ke Indonesia di samping juga melalui pembelian mesin-mesin dan berbagai lokakarya. ${ }^{16}$

Kedua; Joint venture. Joint venture adalah bentuk yang telah lama berkembang cukup pesat dan luas. Suatu kontrak joint venture atau kontrak usaha patungan adalah suatu upaya dari suatu kegiatan komersial (dengan resiko) oleh dua orang atau lebih pihak (yang bertindak) melalui suatu atau lembaga atau organisasi yang dibentuk untuk melaksanakan tujuan bersama. ${ }^{17}$

Sunarayati Hartono memberi batasan joint venture secara luas sebagai berikut: "setiap usaha bersama antara modal Indonesia dan modal asing, baik ia merupakan usaha bersama antara swasta dan swasta, pemerintah, dan swasta, ataupun pemerintah dan pemerintah. Selain itu, tidak dibedakan apakah joint venture itu dianggap sebagai Penanaman Modal Asing ataupun Penanaman Modal dalam Negeri.

Pertama, Licensing, adalah suatu perizinan yang diberikan oleh pemberi lisensi kepada pihak penerima lisensi untuk melaksanakan suatu kegiatan atau suatu hak yang dilindungi. Dengan adanya perizinan ini pihak kedua memungkinkan untuk menikmati penggunaan suatu hak atas kekayaan intelektual di bidang industri. Dengan adanya izin penggunaan ini, pihak pertama mendapatkan pembayaran. ${ }^{18}$

Kedua, Franchising. Dalam Peraturan Menteri Perdagangan No. 12/M-Dag/Per/3/2006 tentang Ketentuan dan Tata Cara Penerbitan Surat Tanda Pendaftaran Usaha Waralaba, ditegaskan bahwa "Waralaba (franchise) adalah perikatan antara pemberi waralaba dengan penerima waralaba di mana penerima waralaba diberikan hak untuk menjalankan usaha dengan memanfaatkan dan/ atau menggunakan hak atas kekayaan intelektual atau penemuan atau ciri khas usaha yang yang dimiliki pemberi waralaba dengan

\footnotetext{
${ }^{16}$ T. Mulya Lubis dan M. Richard Bukbaum, Peranan Hukum Perekonomian di Negara-Negara Berkembang, (Yayasan Obor Indonesia: Jakarta, 1986), h. 128.

${ }^{19}$ Huala Adolf, Dasar-Dasar Hukum Kontrak Internasional, (Bandung, Refika Aditama, 2007), h. 117.
} 
imbalan berdasarkan persyaratan yang ditetapkan oleh pemberi waralaba dengan sejumlah kewajiban menyediakan dukungan konsultasi operasional yang berkesinambungan oleh pemberi waralaba kepada penerima waralaba"

Beberapa mekanisme alih teknnologi di atas merupakan tipe kegiatan yang telah banyak dikenal, sedangkan mekanisme pengalihan teknologi yang lain juga terdapat beberapa seperti: Management contracts, Marketing contracts, Tekhnical service contracts, Turnkey contracts, International subcontracting.

\section{Analisis Alih Teknologi dalam Kerangka Hukum Nasional}

"Perekonomian nasional diselengggarakan berdasar atas demokrasi ekonomi dengan prinsip kebersamaan, efisiensi berkeadilan, berkelanjutan, berwawasan lingkungan, serta dengan menjaga keseimbangan, kemajuan dan kesatuan ekonomi nasional", hal ini yang tertuang dalam pasal 33 ayat 4 Undang-Undang Dasar 1945. Asas-asas tersebut yang kemudian juga diimplementasikan dalam prinsip-prinsip Penanaman Modal di Indonesia dalam Undang-Undang Nomor 25 Tahun 2007. ${ }^{19}$

Dalam kaitannya dengan prinsip kemandirian, keberadaan investasi asing melalui perusahaan-perusahaan transnasional sangat dibutuhkan meskipun dalam prakteknya terdapat sebagian dari perusahaan yang kemudian tidak membuka informasi yang terkandung di dalamnya teknologi yang dipergunakan dalam pelaksanaan produksinya. Akibatnya alih teknologi tidak dapat berjalan sesuai dengan apa yang diharapkan oleh negara berkembang. ${ }^{20}$

Dengan memegang teguh prinsip kemandirian ini, maka kita dapat belajar dari pengalaman Jepang, Cina, dan Korea Selatan yang menerapkan strategi catch up dan applied research. Pada hakikatnya teknologi terbagi menjadi 2 (dua) bagian, yaitu bagian pertama teknologi yang dilindungi paten; dan bagian kedua yang tidak dipatenkan termasuk keahlian (skill) dan keterampilan (technical know how)

\section{Teknologi yang Dilindungi Hak Paten}

Perlindungan hak milik intelektual adalah perlindungan terhadap setiap hak yang timbul dari hasil kreativitas (creativity) dan penemuan (innovation) manusia dalam bidang ilmu pengetahuan dan teknologi, dan dalam bidang perdagangan dan industri. ${ }^{21}$

Dalam kerangka hukum Internasional terdapat lembaga WIPO (World Intellectual Property Organization) yang merupakan organisasi internasional yang secara khusus didirikan untuk mengkoordinasi kerjasama antar negara

\footnotetext{
${ }^{19}$ Lihat pasal 3 Undang-Undang Nomor 25 Tahun 2007 tentang Penanaman Modal

${ }^{20}$ Sabartua Tampubolon, Politik Hukum Iptek di Indonesia (Yogyakarta: Kepel Press, 2013), h. 266

${ }^{21}$ Lebih jauh lihat David L. Perrott, Current Issues in International Business Law, 1988, h. 44-45.
} 
dalam bidang perlindungan hak miliki intelektual. Indonesia telah meratifikasi Konvensi WIPO dengan Keppres No. 24 Tahun $1974 .^{22}$

Dalam kerangka hukum nasional Indonesia memiliki perangkat hukum yang mengatur tentang perlindungan Paten, yakni dalam UndangUndang Nomor 14 Tahun 2000. Paten sendiri merupakan hak eksklusif yang diberikan oleh negara kepada inventor atas hasil invensinya di bidang teknologi untuk selama waktu tertentu melaksanakan sendiri invensinya ${ }^{23}$ atau memberikan persetujuan kepada pihak lain untuk melaksanakan. ${ }^{24}$

Dalam praktek permintaan paten di Indonesia secara kuantitatif dapat dijelaskan bahwa permintaan paten hanya sedikit yang berasal dari dalam negeri, selainnya jumlah terbesar berasal dari luar negeri. Karena hal ini maka untuk menunjang dan mempercepat laju indutrialisasi, perjanjian lisensi memiliki peranan yangsangat penting.

Perjanjian lisensi merupakan sebuah konsekuensi logis dari diundangkannya Undang-Undang Paten, lebih dari itu hal ini merupakan bagian dari globalisasi ekonomi dunia. Regulasi mengenai lisensi paten ini penting untuk diperhatikan agar investor asing merasa aman dengan kepastian dalam perlindungan hukum di Indonesia.

Pada pasal 71 ayat (1) terdapat larangan terkait perjanjian lisensi: a). Perjanjian lisensi yang membawa akibat yang merugikan perekonomian Indonesia; b). Perjanjian lisensi yang dilarang memuat ketentuan pembatasanpembatasan yang menghambat kemampuan bangsa Indonesia dalam menguasai dan mengembangkan teknologi pada umumnya dan yang berkaitan dengan yang diberi paten tersebut pada khususnya. Namun permasalahan yang muncul dari pasal tersebut adalah tidak terdapat penjelasan yang jelas terutama larangan tersebut mengenai apa yang dimaksud dan apa pengertiannya. ${ }^{25}$

\section{Teknologi yang Tidak Dilindungi Paten (Keahlian dan Keterampilan)}

Keahlian (skill) dan keterampilan (technical know how) yang menurut Istvan Gazda didefinisikan sebagai "knowledge and experience of a technical, commercial, administration, financial or other nature, which is practically

\footnotetext{
${ }^{22}$ Berkaitan dengan perlindungan atas Hak Kekayaan Intelektual (HKI)ini terdapat permasalahn yang rumit. Forum GATT (General Agreement on Tariffs and Trade) yang semula dibentuk untuk tujuan penanganan masalah tariff dan perdagangan, sejak tahun 1980 telah memperluas perhatiannya ke arah hak milik intelektual. Konferensi-konferensi GATT, sejak itu tidak hanya terbatas membahas perlindungan merk dagang tapi bahkan penempatan masalah hak milik intelektual secara keseluruhan. Lihat Ida Bagus Wyasa Putra, Aspek Hukum Perdata Internasional: Dalam Transaksi Bisnis Internasional, (Bandung: Refika Aditama, 2000), h. 47.

${ }^{23}$ Invensi (penemuan) adalah ide inventor yang dtuangkan ke dalam suatu kegiatan pemecahan masalah yang spesifik di bidang teknologi, dapat berupa produk atau proses atau penyempurnaan dan pengembangan produk dan proses.

${ }^{24}$ Elsi Kartika Sari dan Advendi Simanunsang, Hukum Dalam Ekonomi, (Jakarta:Grasindo, 2008), h. 120.

${ }^{25}$ OK. Saidin, Aspek Hukum Kekayaan Intelektual: Intelectual Property Rights, (Jakarta: Raja Grafindo Persada, 2004), h. 283.
} 
applicable to the operation of an enterprise or the practice of a profession. ${ }^{, 26}$ (pengetahuan dan pengalaman teknis, perdagangan, administrasi, keuangan atau hal-hal umum lain, yang praktis berlaku untuk beroperasinya suatu perusahaan atau praktek profesi).

Boleh saja sebuah teknologi didaftarkan menjadi sebuah paten, tetapi alih teknologi dapat terjadi, apabila sumber daya manusia dalam suatu negara mau mempelajari dan menguasai, bahkan mampu mengembangkan teknologi yang lebih mutakhir dengan mendasarkan pada teknologi atau invensi sebelumnya. Dalam praktiknya, hanya dengan kemauan untuk belajar terus menerus dan senantiasa memiliki kepercayaan diri melalui pengalaman yan diperoleh dari proses interaksi dengan dunia luar, memungkinkan prinsip kemadirian dalam proses alih teknologi dapat diwujudkan dalam kenyataan.

Regulasi nasional lain mengenai pentingnya alih teknologi bagi bangsa Indonesia dapat dilihat dalam UU Sisnas P3 Iptek yang menyatakan bahwa: $:^{9 \ngtr}$

"bagi Indonesia, alih teknologi melalui investasi badan usaha dari negara-negara maju berpotensi menghasilkan dampak ekonomi yang besar apabila kegiatan usaha dari perusahaan asing tersebut dapat dikaitkan dengan jaringan produsen domestic dalam rantai pertambahan nilai produksi. Melalui keterkaitan itu terbentuk mekanisme demand-suppy yang disertai dngan berbagai persyaratan mutu, kinerja, dan biaya teknologi sehingga produsen domestik yang terlibat didorong untuk memenuhinya. Alih teknologi melalui saluran ini tidak dapat berjalan secara efektif apabila badan usaha domestik tidak siap dan tidak mampu memenuhi persyaratan mutu, kinerja, dan biaya teknologi yang bertaraf internasional sehingga tidak memiliki kelayakan untuk berperan sebagai pemasok perusahaan-perusahaan asing tersebut. Sebaliknya persyaratan di atas dapat dipenuhi, badan usaha domestik tidak hanya dapat menjadi pemasok bagi perusahaan asing yang berusaha di dalam negeri, namun dapat pula menjadi pemasok pasar global. Cara yang terbaik adalah mendorong perkembangan kemampuan badan usaha domestik agar dapat memiliki daya serap kemajuan ilmu pengetahuan dan teknologi. Untuk itu, kemitraan badan usaha dengan perguruan tinggi dan lembaga litbang merupakan faktor yang sangat penting. Perguruan tinggi dan lembaga LITBANG dapat berperan sebagai simpul-simpul jaringan yang dapat bermanfaat bagi badan usaha domestic untuk memantau dan menguasai kemajuan ilmu pengetahuan dan teknologi, serta menggali potensi pemanfaatannya sehingga resiko badan usaha dalam mengadopsi kemajuan ilmu pengetahuan dan teknologi dapat diperkecil".

Peraturan Pemerintah Nomor 20 Tahun 2005 tentang Alih Teknologi Kekayaan Intelektual serta Hasil Penelitian dan Pengembangan oleh Perguruan Tinggi dan Lembaga Penelitian dan Pengembangan yang didelegasikan dalam UU Nomor 18 Tahun 2002 tentang Sisnas P3 Iptek, tidak memberikan banyak penegasan perlunya alih teknologi tersebut. Melainkan hanya memberi batasan

\footnotetext{
${ }^{26}$ Istvan Gazda, Transfer of Technology, (London: The Hague Kluwer Law International, 1996), h. 1.

${ }^{27}$ Lihat Penjelasan Umum UU No. 18 Tahun 2002 tentang Sisnas P3 Iptek.
} 
berupa tujuan alih teknologi kekayaan intelektual serta hasil kegiatan penelitian dan pengembangan, yakni: 1). Menyebarluaskan ilmu pengetahuan dan teknologi; 2). Meningkatkan kemampuan masyarakat dalam memanfaatkan dan menguasai ilmu pengetahuan dan teknologi guna kepentingan masyarakat dan negara. ${ }^{28}$

\section{Peluang dan Hambatan Pelaksanaan Alih Teknologi dalam Investasi Asing di Indonesia}

Teknologi tidak dapat dipisahkan dengan upaya peningkatan standar mutu komoditas yang dihasilkan oleh satu negara. Keunggulan suatu komoditas merupakan keunggulan yang melekat pada suatu komoditas yang dihasilkan oleh negara dibandingkan dengan komoditas serupa yang diproduksi negara lain.

Peluang Indonesia sebagai negara tujuan investasi asing memiliki beberapa keunggulan, yakni keunggulan mutlak (absolute advantage) dan keunggulan komparatif (comparative advantage). ${ }^{29}$ Keunggulan mutlak (absolute advantage) yang dimiliki Indonesia adalah terkait dengan potensi Sumber Daya Alam (SDA) yang dimiliki. Sedangkan keunggulan komparatif (comparative advantage) yang dimiliki Indonesia adalah berkaitan dengan ketersediaan faktor produksi yakni terkait dengan tenaga kerja dan bahan baku yang lebih murah.

Keunggulan-keunggulan yang dimiliki Indonesia tersebut memberikan daya tarik tersendiri bagi investasi asing.Investasi asing yang masuk ke Indonesia inilah yang kemudian membawa teknologi dari negara-negara maju yang dapat digunakan untuk meningkatkan kemampuan teknologi menuju kemandirian teknologi nasional.

Alih teknologi dalam investasi bukanlah sebuah proses tanpa hambatan. Hambatan-hambatan yang ditemukan di lapangan saat ini diantaranya: ${ }^{30}$

Pertama, Hambatan Eksternal, meliputi: a). Sistem internasional kurang mendukung, lebih banyak menguntungkan negara industri maju; b). Bargaining position negara sedang berkembang lemah.

Kedua, Hambatan internal, meliputi: a). Sumber daya manusia dalam jumlah besar dengan tingkat pendidikan rendah; b). Minimnya jumlah modal yang tersedia; c). Tingkat teknologi masih rendah; d). Kurangnya keterampilan (skill) dan knowledge; e). Manajemen organisasi dan pemasaran lemah; f). Sosial dan budaya yang kurang mendukung; g). Sistem pendidikan kurang terencana baik.

\footnotetext{
${ }^{28}$ Sabartua Tampubolon, Politik Hukum Iptek di Indonesia, (Yogyakarta: Kepel Press, 2013), h. 247.

${ }^{29}$ Gunawan Widjaja dan Ahmad Yani, Seri Hukum Bisnis Transaksi Bisnis Internasional: Ekspor-Impor dan Imbal-Beli, (Jakarta: Rajagrafindo Persada, 2001), h. 2.

30 Rosyidah Rakhmawati, Hukum Penanaman Modal di Indonesia, (Malang: Bayumedia, 2004), h. 86.
} 
Dari semua hambatan yang ada di atas terdapat satu hambatan yang menjadi sebuah akar permasalahan alih teknologi Indonesia, yakni hukum yang mengatur mengenai alih teknologi. Pembicaraan mengenai alih teknologi ini sebenarnya telah lama menjadi wacana saat untuk pertama kalinya UndangUndang Nomor 1 Tahun 1967 tentang Penanaman Modal Asing diundangkan. Badan Koordinasi Penanaman Modal mengadakan berbagai kegiatan termasuk menyiapkan rancangan akademik mengenai alih teknologi.

Berlakunya Undang-Undang Nomor 25 Tahun 2007 tentang Penanaman Modal yang berasaskan kemandirian menjadi sebuah komitmen untuk menempatkan investasi asing menjadi sebuah awal untuk mewujudkan kemandirian dan mengurangi ketergantungan terhadap teknologi yang berasal dari luar negeri.

Hal ini penting, karena bercermin dari pengalaman negara maju, upaya penguasaan dan keunggulan di bidang iptek merupakan kunci kemandirian setiap bangsa dalam peningkatan kesejahteraan masyarakatnya maupun dalam memenangkan persaingan di tingkat global.

Hambatan alih teknologi lain yang dikemukakan oleh Philip L. Gardner. Menurut Philip, terdapat sedikitnya dua persoalan yang secara historis menghambat alih teknologi ke negara-negara berkembang. Pertama, kapasitas teknis dari negara berkembang tersebut tidak memadai untuk menyerap dan menggunakan teknologi yang dialihkan. Kedua, dalam konteks perdagangan perdagangan internasional, penguasaan atas teknologi canggih adalah keunggulan komparatif dari negara-negara maju, di mana hal tersebut membuat mereka secara alamiah berusaha mempertahankan keunggulan tersebut dengan membuat mekanisme alih teknologi yang sarat dengan persyaratan atau pembatasan untuk mencegah negara penerima dapat menguasai teknologi itu sepenuhnya.

\section{Hukum Sebagai Pendorong Alih Teknologi}

Law as a tool of social engineering (hukum adalah alat rekayasa sosial) hal inilah yang disampaikan oleh Roscoe Pound. Intinya adalah hukum sebagai sarana atau alat untuk mengubah masyarakat ke arah yang lebih baik, secara pribadi ataupun dalam masyarakat. ${ }^{31}$ Dalam konteks ini peraturan alih teknologi dalam investasi juga menjadi sebuah upaya rekayasa untuk bagaimana terciptanya alih teknologi dalam investasi asing di Indonesia.

Konsepsi hukum sebagai sarana pembaharuan adalah hukum dalam arti kaidah atau peraturan hukum memang dapat berfungsi sebagai pengatur ke arah kegiatan manusia yang dikehendaki oleh pembangunan atau pembaharuan. ${ }^{32}$ Pengaturan alih teknologi dalam investasi di Indonesia bertujuan untuk adanya akselerasi pertumbuhan inovasi dan daya saing ekonomi nasional secara keseluruhan.

\footnotetext{
${ }^{31}$ Efran Helmi Juni, Filsafat Hukum, (Bandung: Pustaka Setia Bandung, 2012), h. 57.

${ }^{32}$ Muchtar Kusumaatmadja, Hukum, Masyarakat dan Pembinaan Hukum Nasional, (Jakarta: Bina Cipta, 1976), h. 4.
} 
Friedman mengatakan bahwa hukum sebagai rekayasa sosial tidak pasif melainkan harus mampu digunakan untuk mengubah suatu keadaan dan kondisi tertentu ke arah yang dituju sesuai dengan kemauan masyarakat, ${ }^{33}$ sehingga hukum berfungsi sebagai agent of modernization and instrument of social engineering.

Menurut Bernard Arief Sidharta cita hukum adalah gagasan, karsa, cipta, dan pikiran berkenaan dengan hukum atau persepsi tentang makna hukum yang dalam intinya terdiri dari 3 unsur: keadian, kehasil-gunaan, (doelmatigheid) dan kepastian hukum. Dari sini regulasi mengenai alih teknologi seharusnya memberikan tidak hanya sebuah kepastian melainkan juga keadilan dan kemanfaatan.

Hukum sebagai pendorong alih teknologi memiliki pengertian adanya platform yang jelas untuk menjadi landasan pelaksanaan alih teknologi dalam inveastasi asing di Indonesia. Menurut Sumantoro, teknologi diperlukan untuk pengembangan industrialisasi, khususnya bagi Indonesia sebagai negara berkembang. Karena itu regulasi mengenai alih teknologi ini harus mencakup hal-hal sebagai berikut: ${ }^{34}$ a). Penciptaan iklim yang menarik dan menguntungkan untuk kegiatan alih teknologi; b). Memberikan keuntungan yang timbal balik bagi phak penerima dan pemberi; c). Mendorong dan memberikan kemudahan dalam alih teknologi; d). Menggunakan prinsip syarat dan kondisi yang adil dan obyektif yang disepakati secara timbal balik; e). Memperhatikan prinsip-prinsip norma internasional (code of conduct); $f$ ). Secara konsisten, pemerintah mengikuti proses pemenuhan kewajiban sesuai dengan hukum internasional.

Selain berkaitan dengan legal substance, peningkatan proses alih teknologi melalui invetasi asing ini juga dapat mengadopsi cara negara Jepang. Di Jepang setiap perjanjian internasional harus memberitahukan Kosei Torihiki linkai/Fair Trade Commission. Dalam Undang-Undang Anti Monopoli Jepang Pasal 6 dan 23 mewajibkan pendaftaran lisensi agar dapat diketahui apakah perjanjian tersebut mengandung unsur monopoli atau tidak. Selain itu dengan mendaftarkan akan dapat diketahui bentuk atau macam teknologi serta royalty yang dikeluarkan. Jadi di Jepang satu badan juga turut berperan dalam pendaftaran perjanjian lisensi yaitu sebagai Bank teknologi. ${ }^{35}$

Penjelasan di atas senada dengan teori sistem hukum yang dikemukakan oleh Lawrence Mere Friedman. Friedman menyebutkan 3 (tiga) inti pemikiran (unsur) dalam sistem hukum, yakni: ${ }^{36}$ a). Legal structure adalah lembaga-lembaga atau instansi yang akan menjalankan proses penegakan hukum; b). Legal substance adalah aturan, norma, dan pola perilaku nyata manusia yang berada di dalam sistem itu; c). Legal culture adalah sikap manusia

\footnotetext{
${ }^{33}$ Mulyana W. Kusumah, Peranan dan Pendayagunaan Hukum dalam Pembangunan, (Bandung: Alumni, 1982), h. 4.

${ }^{34}$ Sumantoro, Masalah Pengaturan Alih Teknologi, (Bandung: Alumni, 1993), h.75.

${ }^{35}$ OK. Saidin, Aspek Hukum Kekayaan Intelektual: Intelectual Property Rights, (Jakarta: Raja Grafindo Persada, 2004), h. 283.

${ }^{36}$ Rustanto, Hukum Nasionalisasi Modal Asing, (Jakarta: Kuwais, 2012), h. 45.
} 
terhadap hukum dan sistem hukum. Ketiga unsur hukum tersebutlah yang akan menunjang tegak dan terlaksanannya alih teknologi dalam investasi asing di Indonesia.

\section{Penutup}

Konsep alih teknologi dalam investasi asing di Indonesia di dasarkan pada asas kemandirian. Berdasarkan bentuknya teknologi sendiri terbagi menjadi 2 yakni teknologi yang dilindungi hak paten dan teknologi yang tidak dilindungi paten. Dalam Undang-Undang Nomor 25 Tahun 2007 alih teknologi yang tidak dilindungi paten dilakukan melalui proses pelatihan yang dilakukan oleh perusahaan penanaman modal kepada tenaga kerja nasional. Alih Teknologi dalam Undang-Undang Nomor 25 Tahun 2007 pasal 10 dilaksanakan melalui cara pelatihan dan peningkatan kemampuan tenaga kerja nasional.

Alih teknologi melalui investasi asing di Indonesia belum memiliki regulasi yang jelas, sehingga di sini kata alih teknologi hanya dipandang sebagai sebuah pilihan bagi investor bukan sebagi suatu kewajiban yang bersifat mengikat dan disertai dengan sanksi tegas. Alih teknologi ini seharusnya dapat diimplementasikan dengan baik apabila terdapat sebuah regulasi yang jelas mengatur dan mensyaratkan alih teknologi sebagai syarat bagi para penanam modal asing untuk mendapatkan berbagai insentif dan kemudahan dalam berinvestasi di Indonesia. Selain itu dengan regulasi yang jelas maka tujuan investasi asing di Indonesia sesuai dengan asas kemandirian dapat tercapai, yakni meningkatkan daya saing dan kemandirian teknologi nasional.

\section{Pustaka Acuan}

Adolf, Huala, Dasar-Dasar Hukum Kontrak Internasional, Bandung, Refika Aditama, 2007.

Damayanti, Doty, Negara Bersumber Daya yang Tidak Berdaya. Dalam Mulyawan Karim, ed. Rindu Pancasila, Jakarta: Kompas Media Nusantara, 2010.

Gazda, Istvan Transfer of Technology, London: The Hague Kluwer Law International, 1996.

H.S, Salim dan Budi Sutrisno, Hukum Investasi, Jakarta; Rajagrafindo Persada, 2008.

Juni, Efran Helmi, Filsafat Hukum, Bandung: Pustaka Setia Bandung, 2012.

Kartika Sari, Elsi dan Advendi Simanunsang, Hukum Dalam Ekonomi, Jakarta:Grasindo, 2008.

Kusumaatmadja, Muchtar, Hukum, Masyarakat dan Pembinaan Hukum Nasional, Jakarta: Bina Cipta, 1976.

Lubis , T. Mulya dan M. Richard Bukbaum, Peranan Hukum Perekonomian di Negara-Negara Berkembang, Yayasan Obor Indonesia: Jakarta, 1986.

Mayana, Ranti Fauza, Perlindungan Desain Industri Di Indonesia dalam Era Perdagangan Bebas, Jakarta; Grasindo, 2004. 
Prasetyantoko, Bencana Finansial, Jakarta:Kompas, 2008.

Perrott, David L, Current Issues in International Business Law, 1988.

Rakhmawati, Rosyidah, Hukum Penanaman Modal di Indonesia, Malang: Bayumedia, 2004.

Rustanto, Hukum Nasionalisasi Modal Asing. Cet-I, Jakarta: Kuwais, 2012.

Rustanto, Hukum Nasionalisasi Modal Asing, Jakarta; Kuwais, 2012.

Saidin, OK, Aspek Hukum Kekayaan Intelektual: Intelectual Property Rights, Jakarta: Raja Grafindo Persada, 2004.

Tampubolon, Sabartua, Politik Hukum Iptek di Indonesia, Cetakan I, Yogyakarta; Kepel Press, 2013.

Tambunan, Tulus TH, Globalisasi dan Perdagangan Internasional, Bogor; Ghalia Indonesia 2004.

Widjaja, Gunawan dan Ahmad Yani, Seri Hukum Bisnis Transaksi Bisnis Internasional: Ekspor-Impor dan Imbal-Beli, Jakarta: Rajagrafindo Persada, 2001.

W. Kusumah, Mulyana, Peranan dan Pendayagunaan Hukum dalam Pembangunan, Bandung: Alumni, 1982. 